\title{
THEORETICAL INVESTIGATION OF FUNDAMENTAL INHERENT PHYSICAL AND OPTOELECTRONIC PROPERTIES OF ZnSnSb 2 CHALCOPYRITE SEMICONDUCTOR
}

\author{
Shalini Tomara, (DShiv Raj Bhardwaj ${ }^{\mathrm{b}}$, Daral Kumar Guptaa, (D)Ajay Singh Verma* \\ ${ }^{a}$ Department of Physics, Banasthali Vidyapith, Rajasthan, (India) 304022 \\ ${ }^{b}$ Department of Physics, B S A College Mathura, (India) 281004 \\ *Corresponding Author: ajay_phy@rediffmail.com, Mobile: +919412884655
}

Received November 18, 2019; revised November 22, 2019; accepted December 18, 2019

\begin{abstract}
Here in, we have investigated fundamental inherent physical properties like as structural, electronic, optical, elastic, thermal etc of the $\mathrm{ZnSnSb}_{2}$ by using the accurate full potential linearized augmented plane wave (FP-LAPW) method. These materials have higher energy gaps and lower melting points as compared to their binary analogues, because of which they are considered to be important in crystal growth studies and device applications. For structural properties, the minimization has been done in two steps, first parameter $\mathrm{u}$ is minimized by the calculation of the internal forces acting on the atoms within the unit cell until the forces become negligible, for this MINI task is used, which is included in the WIEN2K code. Second, the total energy of crystal is calculated for a grid of volume of the unit cell (V) and c/a values. Five values of c/a are used for each volume and a polynomial is fitted to the calculated energies to calculate the best c/a ratio. We have presented the electronic and optical properties with the recently developed density functional of Tran and Blaha. Furthermore, optical features such as dielectric functions, refractive indices, extinction coefficient, optical reflectivity, absorption coefficients, optical conductivities, were calculated for photon energies up to $40 \mathrm{eV}$. We have used WC and TB-mBJ exchange correlation potential for these properties and yield a direct band gap of $0.46 \mathrm{eV}$ for this material and the obtained electronic band gap matches well with the experimental data. The TB-mBJ potential gives results in good agreement with experimental values that are similar to those produced by more sophisticated methods, but at much lower computational costs. The main peaks of real part of the electronic dielectric function $\varepsilon_{1}(\omega)$ which is mainly generated by electronic transition from the top of the valence band to the bottom of conduction band, occurs at $1.59 \mathrm{eV}$ and $\varepsilon_{1}(\omega)$ spectra further decreases up to $4.99 \mathrm{eV}$. The imaginary part of the electronic dielectric constant $\varepsilon_{2}(\omega)$ is the fundamental factor of the optical properties of a material. The proposed study shows that the critical point of the $\varepsilon_{2}(\omega)$ occurs at $0.42 \mathrm{eV}$, which is closely related to the obtained band gap value $0.46 \mathrm{eV}$. The maximum reflectivity occurs in region 3.74-11.33 eV. This material has non-vanishing conductivity in the visible light region $(1.65 \mathrm{eV}-3.1 \mathrm{eV})$, the main peak occurs at $3.80 \mathrm{eV}$, which fall in the UV region. The elastic constants at equilibrium in BCT structure have also determined. The elastic stiffness tensor of chalcopyrite compounds has six independent components, because of the symmetry properties of the space group, namely $\mathrm{C}_{11}, \mathrm{C}_{12}, \mathrm{C}_{13}, \mathrm{C}_{33}, \mathrm{C}_{44}$ and $\mathrm{C}_{66}$ in Young notation. The thermal properties such as thermal expansion, heat capacity, Debye temperature, entropy, Grüneisen parameter and bulk modulus were calculated employing the quasi-harmonic Debye model at different temperatures and pressures and the silent results were interpreted. To determine the thermodynamic properties through the quasi-harmonic Debye model, a temperature range $0 \mathrm{~K} 500 \mathrm{~K}$ has been taken. The pressure effects are studied in the $0-7 \mathrm{GPa}$ range. Similar trends have been observed in the considered temperature range, but above $600 \mathrm{~K}$ trends get disturbed which may be due to melting of material. Based on the semi-empirical relation, we have determined the hardness of the materials, which attributed to different covalent bonding strengths. Most of the investigated parameters are reported for the first time.
\end{abstract}

KEYWORDS: Ab-initio calculations; electronic properties; optical properties; elastic constants; thermal properties

The $\mathrm{A}^{\mathrm{II}} \mathrm{B}^{\mathrm{IV}} \mathrm{C}_{2}{ }^{\mathrm{V}}$ semiconductors have recently received attention due to their potential usage in various nonlinear laser devices [1-3], i.e. second harmonic generation, sum mixing, difference frequency generation and parametric oscillation covering a broad part of the electromagnetic spectrum from ultraviolet to the infrared through the visible region. These materials have higher energy gaps and lower melting points as compared to their binary analogues, because of which they are considered to be important in crystal growth studies and device applications. Apart from it, the other important technological applications of these materials are in light emitting diodes, infrared detectors, infrared oscillations, etc [4-8].

A considerable amount of experimental and theoretical work related to the prediction of crystal structures, lattice constants, phase diagrams and related properties has been done during the last few years [9-13]. But comparatively, less attention, however, has been paid to the $\mathrm{ZnSnSb}_{2}$ which adopts a chalcopyrite structure [14,15]. Tenga et al [16] have studied the high temperature form of $\mathrm{ZnSnSb}_{2}$ which adopted a disordered cubic sphalerite structure where $\mathrm{Zn}$ and $\mathrm{Sn}$ atoms are randomly distributed over the same crystallographic position. A first principles investigation by the same group suggests that the tetragonal low-temperature form of $\mathrm{ZnSnSb}_{2}$ has a narrow band gap of about $0.2 \mathrm{eV}$ in agreement with the semimetal behavior of the material. Very recently, Mishra et al [17] have demonstrated the effect of the $\mathrm{p}-\mathrm{d}$ hybridization, structural distortion and cation electronegativity on the band gap of the $\mathrm{ZnSnSb}_{2}$ by using Tight binding Linear Muffin-Tin orbital method.

In the paper we present the structural, electronic, optical, elastic and thermal properties of $\mathrm{ZnSnSb}_{2}$ in chalcopyrite phase. We have presented the theoretical study of expansion coefficient $(\alpha)$, heat capacities $\left(\mathrm{C}_{\mathrm{v}}\right.$ and $\left.\mathrm{C}_{\mathrm{p}}\right)$, bulk modulus $(\mathrm{B}$ and $\left.\mathrm{B}_{\mathrm{s}}\right)$, Debye temperature $\left(\theta_{\mathrm{D}}\right)$, hardness $(\mathrm{H})$ and Gruneisen parameter $(\gamma)$ of $\mathrm{ZnSnSb}_{2}$ which are nevertheless scarce in literature. The outline of the paper is as follows. In section II we have given a brief review of the computational scheme 
used. The calculations of the structural, electronic and optical properties along with the computed elastic and thermal properties are described in section III; while the summary and conclusions are drawn in section VI.

\section{COMPUTATIONAL METHODS}

The calculations were done using FP-LAPW computational scheme $[18,19]$ as implemented in the WIEN2K code [20]. The FP-LAPW method expands the Kohn-Sham orbitals in atomic like orbitals inside the muffin-tin (MT) atomic spheres and plane waves in the interstitial region. The Kohn-Sham equations were solved using the recently developed Wu-Cohen generalized gradient approximation (WC-GGA) [21,22] for the exchange-correlation (XC) potential. It has been shown that this new functional is more accurate for solids than any existing GGA and meta-GGA forms. For a variety of materials, it improves the equilibrium lattice constants and bulk moduli significantly over localdensity approximation [23] and Perdew-Burke-Ernzerhof (PBE) [24] and therefore is a better choice. For this reason we adopted the new WC approximation for the XC potential in studying the present systems. Further for electronic structure calculations modified Becke-Johnson potential (TB-mBJ) [25] as coupled with WC-GGA is used.

The valence wave functions inside the atomic spheres were expanded up to $l=10$ partial waves. In the interstitial region, a plane wave expansion with $R_{\mathrm{MT}} K_{\max }$ equal to seven was used for all the investigated systems, where $\mathrm{R}_{\mathrm{MT}}$ is the minimum radius of the muffin-tin spheres and $K_{\max }$ gives the magnitude of the largest $\mathrm{K}$ vector in the plane wave expansion. The potential and the charge density were Fourier expanded up to $\mathrm{G}_{\max }=10$. We carried out convergence tests for the charge-density Fourier expansion using higher $G_{\max }$ values. The $\mathrm{R}_{\mathrm{MT}}$ (muffin-tin radii) are taken to be 2.2, 2.22 and 2.15 (in atomic unit) for $\mathrm{Zn}, \mathrm{Sn}$ ans $\mathrm{Sb}$ respectively. The modified tetrahedron method [26] was applied to integrate inside the Brillouin zone (BZ) with a dense mesh of 5000 uniformly distributed k-points (equivalent to 405 in irreducible BZ) where the total energy converges to less than $10^{-6} \mathrm{Ry}$.

\section{RESULTS AND DISSCUSSION Structural Properties}

The ternary chalcopyrite semiconductor crystallizes in the chalcopyrite structure with sapce group $I-\overline{42} d\left(D_{2 d}^{12}\right)$. The $\mathrm{Zn}$ atom is located at $(0,0,0) ;(0,1 / 2,1 / 4)$, Sn at $(1 / 2,1 / 2,0) ;(1 / 2,0,1 / 4)$ and $\mathrm{Sb}$ at $(\mathrm{u}, 1 / 4,1 / 8) ;(-\mathrm{u}, 3 / 4,1 / 8) ;(3 / 4, \mathrm{u}, 7 / 8)$; $(1 / 4,-u, 7 / 8)$. Two unequal bond lengths $d_{\mathrm{Zn}-\mathrm{Sb}}$ and $\mathrm{d}_{\mathrm{Sn}-\mathrm{Sb}}$ result in two structural deformations, first is characterized by $\mathrm{u}$ parameter defined as $\mathrm{u}=0.25+\left(\mathrm{d}_{\mathrm{Zn}-\mathrm{Sb}}{ }^{2}-\mathrm{d}_{\mathrm{Sn}-\mathrm{Sb}}{ }^{2}\right) / \mathrm{a}^{2}$ where $\mathrm{a}$ is the lattice parameter in $\mathrm{x}$ and $\mathrm{y}$ direction, and the second parameter $\eta=c / a$, where $\mathrm{c}$ is lattice parameter in $\mathrm{z}$ direction which is generally different from 2a.

To determine the best energy as a function of volume, we minimized the total energy of the system with respect to the other geometrical parameters. The minimization is done in two steps, first parameter $\mathrm{u}$ is minimized by the calculation of the internal forces acting on the atoms within the unit cell until the forces become negligible, for this MINI task is used which is included in the WIEN2K code. Second, the total energy of crystal is calculated for a grid of volume of the unit cell $(\mathrm{V})$ and c/a values, where each point in the grid involves the minimization with respect to u. Five values of c/a are used for each volume and a polynomial is then fitted to the calculated energies to calculate the best c/a ratio. The result is an optimal curve (c/a, u) as a function of volume. Further a final optimal curve of total energy is obtained by minimizing the energy verses $[\mathrm{V}, \mathrm{c} / \mathrm{a}(\mathrm{V}), \mathrm{u}(\mathrm{V})]$ by FP-LAPW calculations and Murnaghan equation of state [27].

Further we have used the calculated lattice constants for determination of inter atomic distance for $\mathrm{A}-\mathrm{C}$ and $\mathrm{B}-\mathrm{C}$ bonds by the following relations [15].

$$
\begin{gathered}
\mathrm{x}=0.5-\left(\mathrm{c}^{2} / 32 \mathrm{a}^{2}-1 / 16\right)^{1 / 2} ; \quad \mathrm{d}_{\mathrm{A}-\mathrm{C}}=\left[\mathrm{a}^{2} \mathrm{x}^{2}+\left(4 \mathrm{a}^{2}+\mathrm{c}^{2}\right) / 64\right]^{1 / 2} ; \\
\mathrm{d}_{\mathrm{B}-\mathrm{C}}=\left[\mathrm{a}^{2}(1 / 2-\mathrm{x})^{2}+\left(4 \mathrm{a}^{2}+\mathrm{c}^{2}\right) / 64\right]^{1 / 2} ; \mathrm{d}(\text { in } \AA)=\left(\mathrm{d}_{\mathrm{A}-\mathrm{C}}+\mathrm{d}_{\mathrm{B}-\mathrm{C}}\right) / 2 .
\end{gathered}
$$

We have also calculated the bulk modulus (B in GPa) by using the semi-empirical equations developed by Verma and co-authors $[28,29]$ for chalcopyrite semiconductors as follows,

$$
\begin{gathered}
B=A+S \times \sqrt[4]{Z_{1} Z_{2} Z_{3}} \times\left(\frac{k_{B} T_{m}}{\Omega}\right), \\
B=4056\left(Z_{1} Z_{2} Z_{3}\right)^{0.15} d^{-5},
\end{gathered}
$$

where $\mathrm{k}_{\mathrm{B}}, \mathrm{T}_{\mathrm{m}}, \Omega$ and $\mathrm{d}$ is the Boltzman's constant, melting temperature, bond volume and inter atomic distance respectively; $\mathrm{Z}_{1} \mathrm{Z}_{2} \mathrm{Z}_{3}$ (product of ionic charges) 48 for $\mathrm{A}^{\mathrm{II}} \mathrm{B}^{\mathrm{IV}} \mathrm{C}_{2}{ }^{\mathrm{V}}$ semiconductors. $\mathrm{A}$ and $\mathrm{S}$ are constants and the values are 9.09042 and 38.47051 respectively for the chalcopyrite semiconductors. Table 1 presents the lattice constants and obtained along with the bulk modulus and its pressure derivative $\left(\mathrm{B}^{\prime}\right)$. The calculated total energy per $\mathrm{ZnSnSb}_{2}$ unit as a function of volume is shown in Fig. 1. 


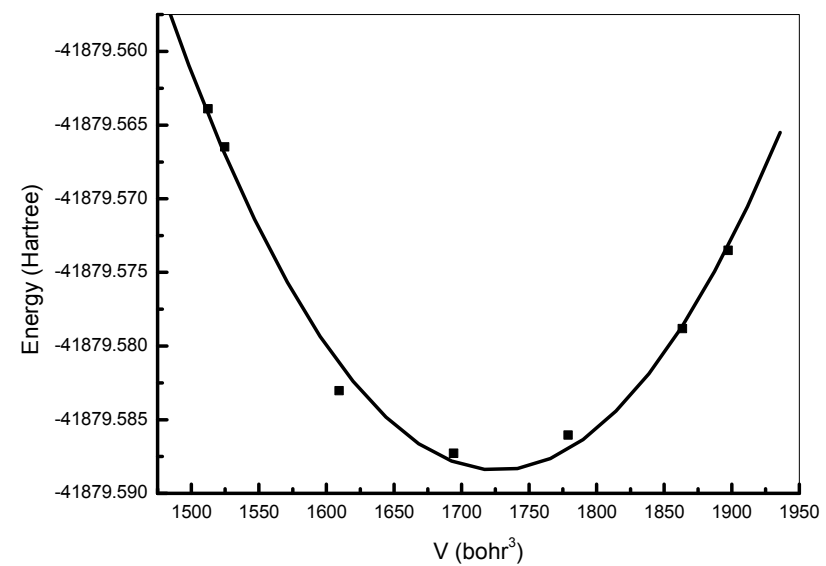

Fig. 1. Calculated total energies as a function of volume of $\mathrm{ZnSnSb}_{2}$

Table 1

The various obtained parameters of $\mathrm{ZnSnSb}_{2}$ calculated in WC-GGA

\begin{tabular}{|c|c|c|c|c|c|}
\hline $\mathrm{a}(\AA)$ & $\mathrm{c}(\AA)$ & $\mathrm{u}$ & $\mathrm{d}(\AA)^{\mathrm{C}}$ & $\mathrm{B}(\mathrm{GPa})$ & $\mathrm{B}^{\prime}$ \\
\hline $6.259^{\#}$ & $12.901^{\#}$ & $0.235^{\#}$ & $2.739^{\$}$ & $46^{\#}$ & $7.978^{\#}$ \\
\hline $6.273^{\$ \$}$ & $12.546^{\$ \$}$ & & $2.716^{\$ \$}$ & $35^{*}, 47^{* *}, 49^{* * *}$ & \\
\hline$\Omega^{\#}\left(10^{-30} \mathrm{~m}^{3}\right)$ & $\mathrm{T}_{\mathrm{m}}(\mathrm{K})^{\#}$ & $\mathrm{n}^{\#}$ & $\mathrm{n}^{\mathrm{D}}$ & $\varepsilon_{\infty}^{\#}$ & $\varepsilon_{\infty}{ }^{\mathrm{E}}$ \\
\hline 32.2122 & $600 \mathrm{~K}$ & 3.693 & 4.157 & 13.64 & 13.0 \\
\hline
\end{tabular}

${ }^{\#}$ this work; ${ }^{\$ \$}$ Reference [15]; ${ }^{\mathrm{C}}$ Calculated from equation (1); ${ }^{\mathrm{D}}$ Calculated from equation (8); ${ }^{\mathrm{E}}$ Calculated from equation (7); $\Omega$ is bond volume, *Calculated from equation (2); **Calculated from equation (3); ***Calculated from equation (3) data taken from Reference [15].

\section{Electronic and optical properties}

The present calculations using the $\mathrm{WC}$ and $\mathrm{TB}-\mathrm{mBJ}$ method yields a direct band gap of $0.46 \mathrm{eV}$ for $\mathrm{ZnSnSb}_{2}$, as shown in Fig. 2(a).

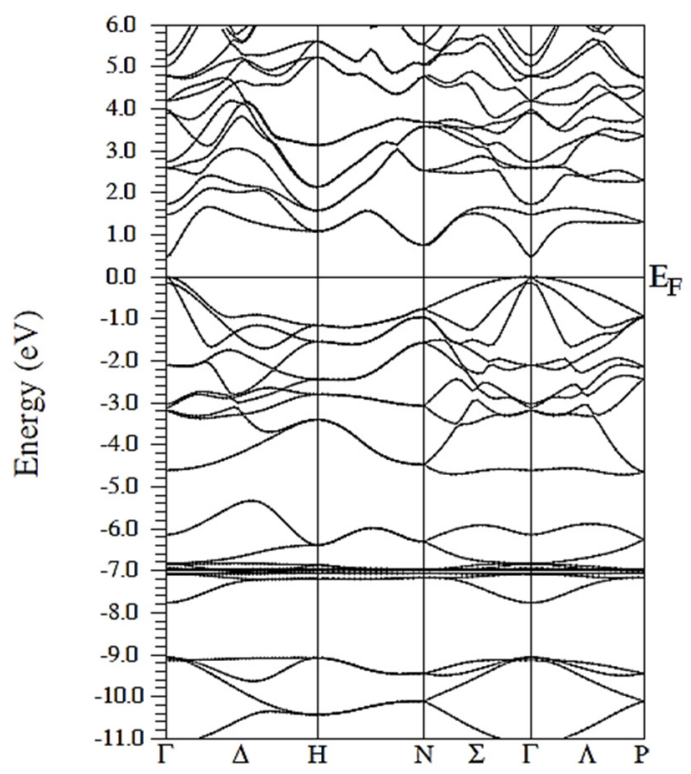

(a)

Fig. 2. Band structure (a) and calculated partial and total density of states (DOS) for $\mathrm{ZnSnSb}_{2}$ (b)
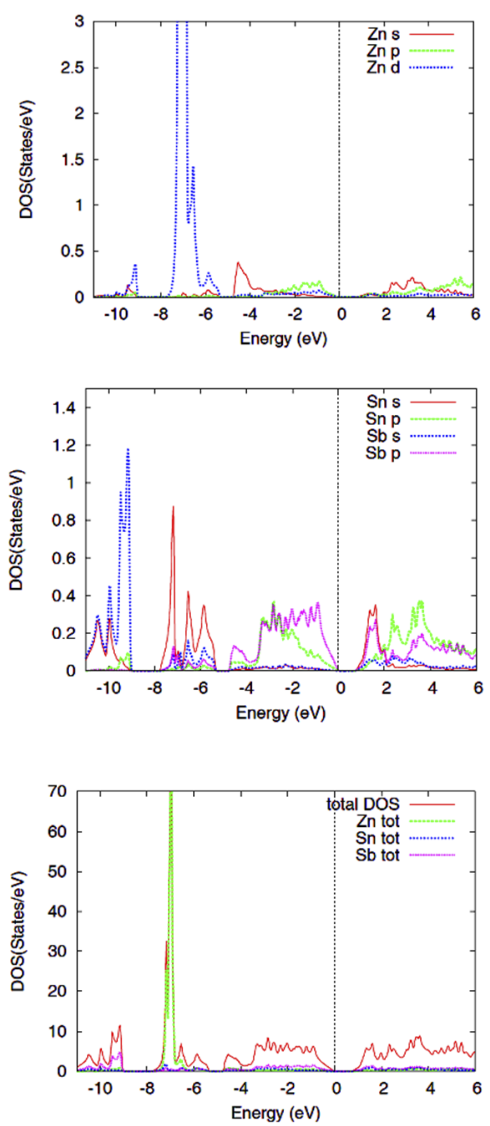

(b) 
As clear from the Fig. 2 that the obtained electronic band gap matches well with the experimental data $(0.4 \mathrm{eV})$ predicted by Kiselyova et al [30]. Mishra et al, [17] and Bhosale et al [31] have been reported an estimate of the theoretical band gap of $\mathrm{ZnSnSb}_{2}$ as $0.19 \mathrm{eV}$ and $0.46 \mathrm{eV}$ respectively. The total and partial density of state (TDOS and PDOS) corresponding to the band structures shown in Fig. 2(b) along with the Fermi energy level for 0 GPa pressure. The position of the Fermi level is at $0 \mathrm{eV}$. The PDOS are very useful as they give information on hybridization and the orbital character of the states. It can be seen that in Fig. 2(b), the lowest valence bands are essentially dominated by Sb-s states, with minor presence Sn-p and Sn-s states. The intermediate valence band is essentially dominated by $\mathrm{Zn}$-d states. The other valence bands are essentially dominated by Sb-s states. The conduction band consists essentially of Sn-s and Sb-p with a minor presence $\mathrm{Sn}-\mathrm{p}$ and $\mathrm{Sb}$-s states. The comparison of the theoretical band gaps with available experimental data shows that TB-mBJ correlation potential allows the prediction of band gap values much closer to the experimental values. The TB$\mathrm{mBJ}$ potential gives results in good agreement with experimental values that are similar to those produced by more sophisticated methods, but at much lower computational costs [25].

The linear response to an external electromagnetic field with a small wave vector is measured through the complex dielectric function,

$$
\varepsilon(\omega)=\varepsilon_{1}(\omega)+i \varepsilon_{2}(\omega),
$$

which is related to the interaction of photons with electrons[32]. The imaginary part $\varepsilon_{2}(\omega)$ of the dielectric function could be obtained from the momentum matrix elements between the occupied and unoccupied wave functions and is given by [33]

$$
\varepsilon_{2}(\omega)=\frac{2 \pi^{2} e^{2}}{\Omega \varepsilon_{0}} \sum_{i \in c . f \in v} \sum_{k}\left|\left\langle\Psi_{k}^{c}|\hat{\mu} \cdot r| \Psi_{k}^{v}\right\rangle\right|^{2} \delta\left[E_{k}^{c}-E_{k}^{v}-\hbar \omega\right] .
$$

The real part $\varepsilon_{1}(\omega)$ can be evaluated from $\varepsilon_{2}(\omega)$ using the Kramer-Kronig relations and is given by[34]

$$
\varepsilon_{1}(\omega)=1+\left(\frac{2}{\pi}\right) \int_{0}^{\infty} \frac{\omega^{\prime 2} \varepsilon_{2}\left(\omega^{\prime}\right)}{\omega^{\prime 2}-\omega^{2}} d \omega^{\prime} .
$$

All of the other optical properties, including the absorption coefficient $\alpha(\mathrm{x})$, the refractive index $\mathrm{n}(\mathrm{x})$, the extinction coefficient $\mathrm{k}(\mathrm{x})$, and the energy-loss spectrum $\mathrm{L}(\mathrm{x})$, can be directly calculated from $\varepsilon_{1}(\omega)$ and $\varepsilon_{2}(\omega)[33,35]$.

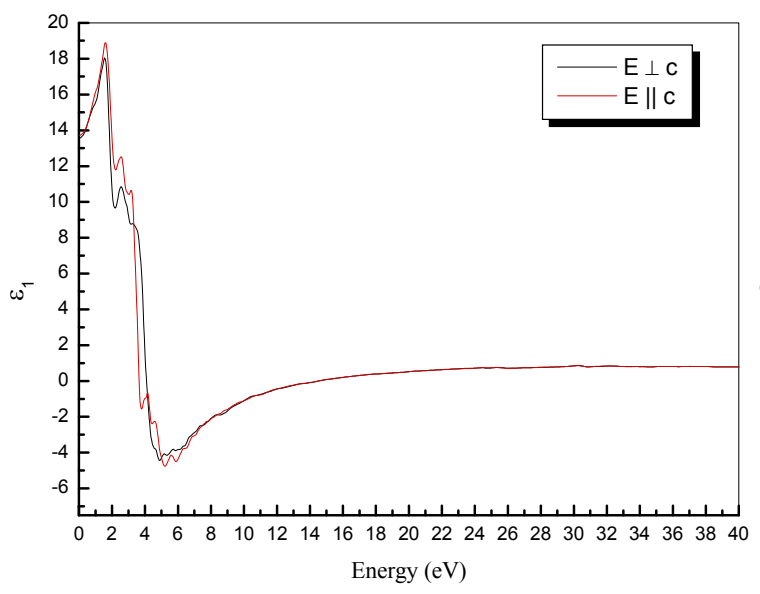

(a)

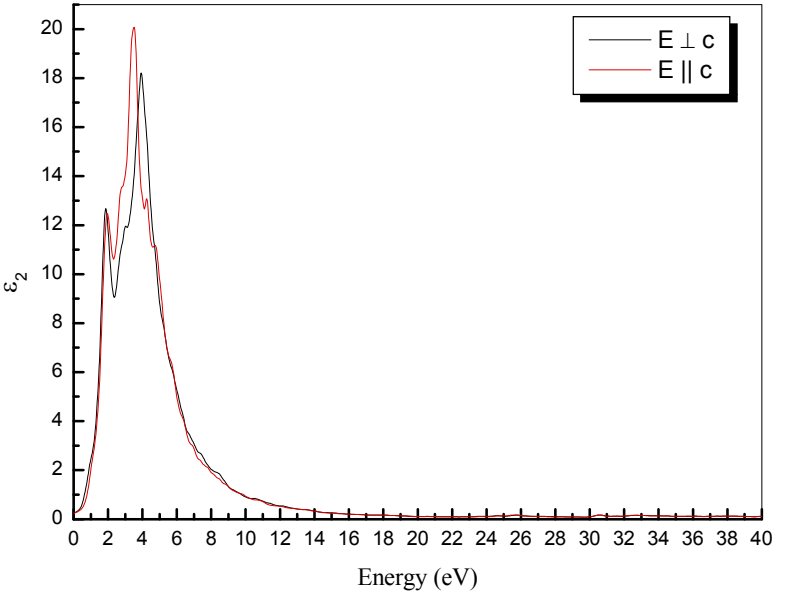

(b)

Fig. 3. The calculated (a) real $\varepsilon_{1}(\omega)$ and (b) imaginary $\varepsilon_{2}(\omega)$ parts of complex dielectric constant for $\mathrm{ZnSnSb}_{2}$

Fig. 3(a) and 3(b) displays the real and imaginary parts respectively of the electronic dielectric functions $\varepsilon(\omega)$ spectrum for the photon energy ranging up to $40 \mathrm{eV}$. The main peaks of real part of the electronic dielectric function $\varepsilon_{1}(\omega)$ which is mainly generated by electronic transition from the top of the valence band to the bottom of conduction band, occurs at $1.59 \mathrm{eV}$ and $\varepsilon_{1}(\omega)$ spectra further decreases up to $4.99 \mathrm{eV}$. Optical spectra exhibit anisotropy in two directions (along basal-plane and z-axis) with a very small difference (0.01517) in the static limit. The imaginary part of the electronic dielectric constant $\varepsilon_{2}(\omega)$ is the fundamental factor of the optical properties of a material. The proposed study shows that the critical point of the $\varepsilon_{2}(\omega)$ occurs at $0.42 \mathrm{eV}$, which is closely related to the obtained band gap value 0.46 $\mathrm{eV}$. This point corresponds to the $\Gamma_{\mathrm{c}}-\Gamma_{v}$ splitting which gives the threshold for the direct optical transitions between the absolute valence band maximum and the first conduction band minimum and is known as fundamental adsorption edge. An estimation of dielectric constant for the comparison can be given by the relation developed by Verma et al [13] for chalcopyrites as follows,

$$
\varepsilon_{X Y}=S\left(Z_{X} Z_{Y}\right)^{A} d_{X Y}^{2}
$$


where $\mathrm{d}_{\mathrm{XY}}$ is the inter atomic distance of (A-C and $\mathrm{B}-\mathrm{C}$ bond). $\mathrm{ZX}_{\mathrm{X}} \mathrm{Z}_{\mathrm{Y}}$ is product of ionic charges of $\mathrm{A}-\mathrm{C}$ and $\mathrm{B}-\mathrm{C}$ bond and the values are 6 and 12 respectively. $\mathrm{A}$ and $\mathrm{S}$ are constants with the values 0.83 and 0.27 respectively for $\mathrm{A}^{\mathrm{II}} \mathrm{B}^{\mathrm{IV}} \mathrm{C}_{2}{ }^{\mathrm{V}}$ semiconductors.

Fig. 4(a),(b) present the refractive index $n(\omega)$ and the extinction coefficient $k(\omega)$ respectively. The refractive index spectrum shows an anisotropic behavior $(\Delta \mathrm{n}(0 \mathrm{eV})=0.02052)$, hence only the average value is listed in Table 1 .

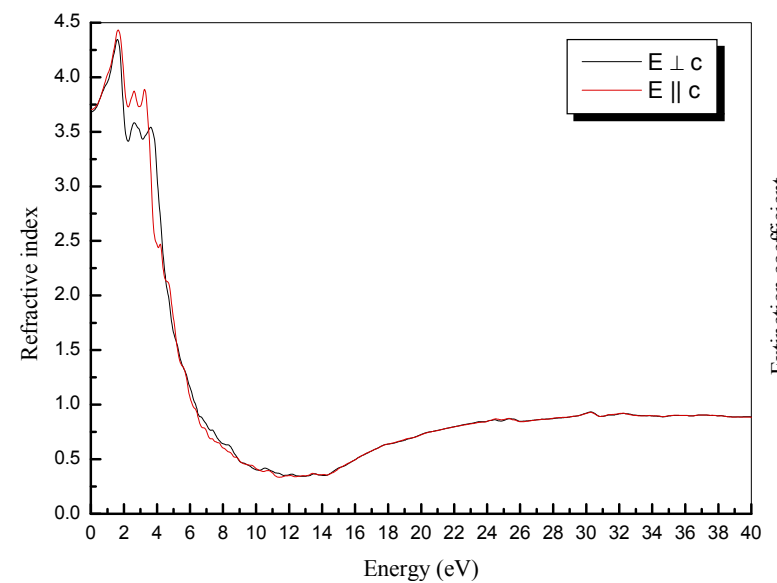

(a)

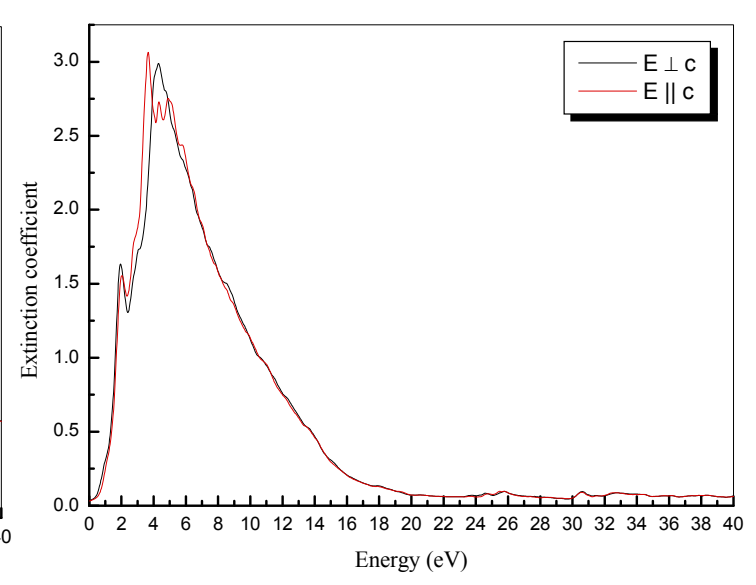

(b)

Fig. 4. The calculated (a) refractive index and (b) extinction coefficient for $\mathrm{ZnSnSb}_{2}$

The refractive index increases with energy reaching a maximum value in the visible region for all compounds. The peak values the refractive index has a value of 4.39 at $1.61 \mathrm{eV}$. The extinction coefficient $\mathrm{k}(\omega)$ is related to the decay or damping of the oscillation amplitude of the incident electric field, the extinction coefficient $\mathrm{k}(\omega)$ decreases with increasing the incident photon energy. The peak value obtained for the extinction coefficient occurs at the point where the dispersive part of dielectric constant $\left(\varepsilon_{1}(\omega)\right)$ has a zero value (Fig. 4(a)) for all the compounds. The extinction coefficient $\mathrm{k}(\omega)$ decreases with increasing the incident photon energy.

The refractive index (n) of these compounds can also be evaluated by using the relation given by Verma et al[36] for chalcopyrites as follows,

$$
n=0.31\left(Z_{1} Z_{2} Z_{3}\right)^{0.15} d^{2},
$$

Where $\mathrm{d}$ is the inter atomic distance and $\mathrm{Z}_{1} \mathrm{Z}_{2} \mathrm{Z}_{3}$ (product of ionic charges) $=48$ for $\mathrm{A}^{\mathrm{II}} \mathrm{B}^{\mathrm{IV}} \mathrm{C}_{2}{ }^{\mathrm{V}}$ semiconductors.

The calculated optical reflectivity R $(\omega)$ and absorption coefficient are $\alpha(\omega)$ displayed in Fig. 5(a),(b) respectively. The maximum reflectivity occurs in region $3.74 \mathrm{eV}-11.33 \mathrm{eV}$. The absorption coefficient indicates the fraction of light lost by the electromagnetic wave when it passes through a unit thickness of the material. It is clear that polarization has a minor influence on the spectrum. From the absorption spectrum, we can easily find the absorption edge at $0.45 \mathrm{eV}$. When the photon energy is more than the absorption edge value, then adsorption coefficient increases. The absorption coefficients further decrease rapidly in the high energy region, which is the typical characteristic of semiconductors. Optical conductivity parameters are closely related to the photo-electric conversion efficiency and mainly used to measure the change caused by the illumination. Fig. 6 shows the optical conductivity of $\mathrm{ZnSnSb}_{2}$. It's clear that the material has non-vanishing conductivity in the visible light region $(1.65 \mathrm{eV}-3.1 \mathrm{eV})$, the main peak occurs at $3.80 \mathrm{eV}$, which fall in the UV region.

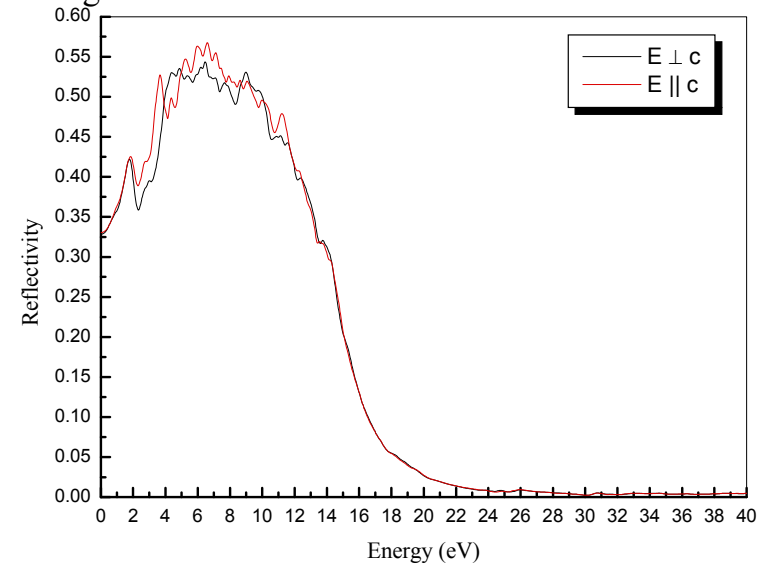

(a)

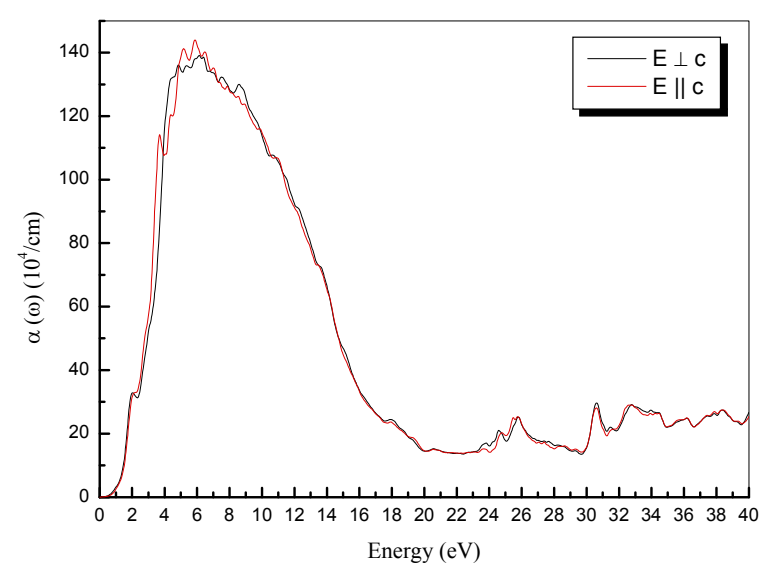

(b)

Fig. 5. The calculated (a) reflectivity $(\mathrm{R}(\omega))$ and (b) absorption coefficient $(\alpha(\omega))$ for $\mathrm{ZnSnSb}_{2}$ 


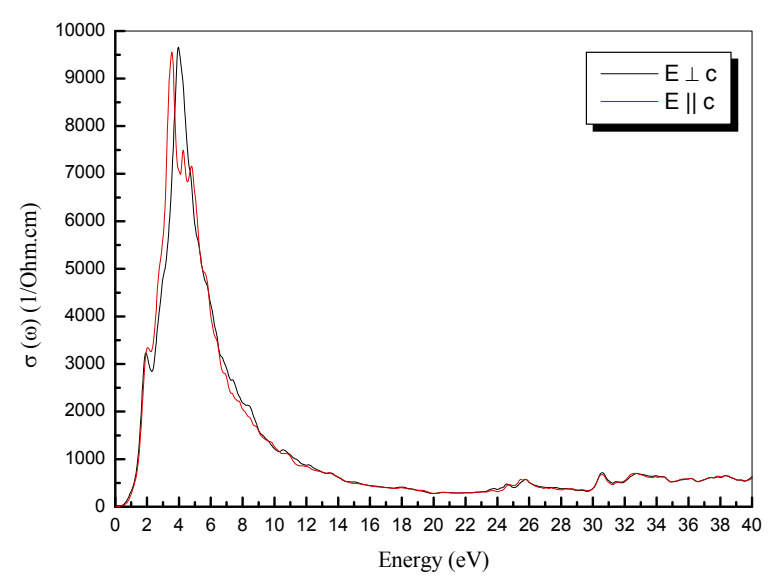

Fig. 6. The calculated photoconductivity $(\sigma(\omega))$ for $\mathrm{ZnSnSb}_{2}$

Elastic Properties

The determination of the elastic constants requires knowledge of the curvature of the energy curve as a function of strain for selected deformations of the unit cell. The deformations [37] are shown in Table 2 and chosen such that the strained systems have the maximum possible symmetry. The WIEN2K package [20] facilitates this task by providing a force-driven optimization of the internal cell geometry. The elastic stiffness tensor of chalcopyrite compounds has six independent components, because of the symmetry properties of the $D_{2 d}^{12}$ space group, namely $\mathrm{C}_{11}, \mathrm{C}_{12}, \mathrm{C}_{13}, \mathrm{C}_{33}, \mathrm{C}_{44}$ and $\mathrm{C}_{66}$ in Young notation. The calculated elastic constant for the tetragonal phase of $\mathrm{ZnSnSb}_{2}$ are listed in Table 3. The calculated elastic constants fulfill the mechanical stability criteria for the tetragonal systems:

$$
\mathrm{C}_{11}>\left|\mathrm{C}_{12}\right|,\left(\mathrm{C}_{11}+\mathrm{C}_{12}\right) \mathrm{C}_{33}>2 \mathrm{C}_{13}{ }^{2}, \mathrm{C}_{44}>0 \text {, and } \mathrm{C}_{66}>0 \text {. }
$$

In order to check the internal consistency of calculated elastic constants we can compare the bulk modulus reported on Table $1 \& 3$ with an equivalent combination of the $\mathrm{C}_{\mathrm{ij}}$ 's.

Table 2.

The lattice parameters of the deformed tetragonal unit cell, the expression relating the $\delta$ and $\varepsilon$ variables, the finite Lagrangian strain tensor (Voigt notation) and the value of the second derivative, $(1 / 2 \mathrm{~V})\left(\mathrm{d}^{2} \mathrm{E} / \mathrm{d} \varepsilon^{2}\right)$, in terms of the elastic constants ( $\varepsilon$ being deformation coordinate and $\mathrm{E}$ the energy)

\begin{tabular}{|c|c|c|c|}
\hline Strained cell & $\varepsilon$ & Strain $(\eta)$ & $\mathrm{dE}^{2} / \mathrm{d}^{2}$ \\
\hline$\left(a+\delta, a+\delta, \frac{c+c \delta}{a}, 90,90,90\right)$ & $\frac{(a+\delta)^{2}}{a^{2}}-1$ & $\left(\frac{\varepsilon}{2}, \frac{\varepsilon}{2}, \frac{c \varepsilon}{2 a}, 0,0,0\right)$ & $\frac{1}{4}\left(C_{11}+C_{12}\right)+\frac{1}{8} C_{33}+\frac{1}{2} C_{13}$ \\
\hline$(a+\delta, a+\delta, c, 90,90,90)$ & $\frac{(a+\delta)^{2}}{a^{2}}-1$ & $\left(\frac{\varepsilon}{2}, \frac{\varepsilon}{2}, 0,0,0,0\right)$ & $\frac{1}{4}\left(C_{11}+C_{12}\right)$ \\
\hline$\left(a, a, \frac{c+c \delta}{a}, 90,90,90\right)$ & $\frac{(c+\delta)^{2}}{c^{2}}-1$ & $\left(0,0, \frac{\varepsilon}{2}, 0,0,0\right)$ & $\frac{1}{8} C_{33}$ \\
\hline$(a, a+\delta, c, 90,90,90)$ & $\frac{(a+\delta)^{2}}{a^{2}}-1$ & $\left(0, \frac{\varepsilon}{2}, 0,0,0,0\right)$ & $\frac{1}{8} C_{11}$ \\
\hline$(a, a, c, 90,90+\delta, 90)$ & $\sin \delta$ & $(0,0,0,0, \varepsilon, 0)$ & $C_{44}$ \\
\hline$(a, a, c, 90,90,90+\delta)$ & $\sin \delta$ & $(0,0,0,0,0, \varepsilon)$ & $C_{66}$ \\
\hline
\end{tabular}

Table 3.

Elastic constants $\mathrm{C}_{\mathrm{ij}}$ (in $\mathrm{GPa}$ ) of $\mathrm{ZnSnSb}_{2}$ compared with available data

\begin{tabular}{|c|c|c|c|c|c|}
\hline $\mathrm{C}_{11}$ & $\mathrm{C}_{12}$ & $\mathrm{C}_{13}$ & $\mathrm{C}_{33}$ & $\mathrm{C}_{44}$ & $\mathrm{C}_{66}$ \\
\hline $63.4^{\#}, 78.7^{*}$ & $39.2^{\#}, 49.2^{*}$ & $33.1^{\#}, 46.7^{*}$ & $65.6^{\#}, 73.8^{*}$ & $49.9^{\#}, 27.1^{*}$ & $74.4^{\#}, 24.6^{*}$ \\
\hline $\mathrm{B}(\mathrm{GPa})^{\#}$ & $\mathrm{G}(\mathrm{GPa})^{\#}$ & $\mathrm{Y}(\mathrm{GPa})^{\#}$ & $v^{\#}$ & $\kappa_{\mathrm{a}}\left(\mathrm{GPa}^{-1}\right)^{\#}$ & $\kappa_{\mathrm{c}}\left(\mathrm{GPa}^{-1}\right)^{\#}$ \\
\hline 45 & 33 & 80 & 0.20 & 0.0072 & 0.0080 \\
\hline *Calculated from equation (29); ${ }^{\#}$ this work
\end{tabular}

Bulk modulus should be found from above by the Voigt approximation (uniform strain assumption) [38-40]:

$$
B_{V}=\frac{1}{9}\left(2 C_{11}+C_{33}+2 C_{12}+4 C_{13}\right)
$$




$$
B_{R}=\frac{\left(C_{11}+C_{12}\right) C_{33}-2 C_{13}^{2}}{C_{11}+C_{12}+2 C_{33}-4 C_{13}} .
$$

Voigt and Reuss approximations provide, in fact, an estimation of the elastic behaviour of an isotopic material, for instance a polycrystalline sample. Such a medium would have a single shear constant, $G$, upper bounded $\left(G_{v}\right)$ and lower bounded $\left(\mathrm{G}_{\mathrm{R}}\right)$ by

$$
\begin{gathered}
G_{V}=\frac{1}{30}\left(M+3 C_{11}-3 C_{12}+12 C_{44}+6 C_{66}\right), \\
G_{R}=15\left\{\frac{18 B_{V}}{C^{2}}+\frac{6}{\left(C_{11}-C_{12}\right)}+\frac{6}{C_{44}}+\frac{3}{C_{66}}\right\}^{-1} ; C^{2}=\left(C_{11}+C_{12}\right) C_{33}-2 C_{13}^{2} .
\end{gathered}
$$

In the Voigt-Reuss-Hill approximation [41], the B and $\mathrm{G}$ of the polycrystalline material are approximated as the arithmetic mean of the Voigt and Reuss limits:

$$
\begin{aligned}
& B=\frac{B_{V}+B_{R}}{2}, \\
& G=\frac{G_{V}+G_{R}}{2} .
\end{aligned}
$$

Finally the Poisson ratio and the Young modulus are obtained as

$$
\begin{aligned}
& v=\frac{3 B-2 G}{2(3 B+G),} \\
& Y=\frac{9 B G}{3 B+G} .
\end{aligned}
$$

Using the single crystal $C_{\mathrm{ij}}$ data, one can evaluate the linear compressibilities along the principles axis of the lattice. For the tetragonal structure, the linear compressibilities $\kappa_{\mathrm{a}}$ and $\kappa_{\mathrm{c}}$ along the a- and c-axis respectively are given in term of elastic constants by the following relations;

$$
\begin{aligned}
& \kappa_{a}=-\frac{1}{a} \frac{\partial a}{\partial p}=\frac{C_{33}-C_{13}}{C_{33}\left(C_{11}+C_{12}\right)-2 C_{13}^{2}}, \\
& \kappa_{c}=-\frac{1}{c} \frac{\partial c}{\partial p}=\frac{C_{11}+C_{12}-2 C_{13}}{C_{33}\left(C_{11}+C_{12}\right)-2 C_{13}^{2}} .
\end{aligned}
$$

Pugh [42] proposed that the resistance to plastic deformation is related to the product Gb, where ' $b$ ' is the Burgers vector, and that the fracture strength is proportional to the product $\mathrm{Ba}$, where ' $\mathrm{a}$ ' corresponds to the lattice parameter. As $\mathrm{b}$ and a are constants for specific materials, the $\mathrm{Ba} / \mathrm{Gb}$ can be simplified into $\mathrm{B} / \mathrm{G}$. This formula was recently exploited in the study of brittle vs ductile transition in intermetallic compounds from first-principles calculations [43, 44]. A high B/G ratio is associated with ductility, whereas a low value corresponds to the brittle nature. The critical value which separates ductile and brittle material is around 1.75 , i.e., if $\mathrm{B} / \mathrm{G}>1.75$, the material behaves in a ductile manner otherwise the material behaves in a brittle manner. We have found that $\mathrm{B} / \mathrm{G}$ ratio is 1.35 , classifying the material as brittle. The $\mathrm{c} / \mathrm{a}$ ratio is $\sim 2.06$, indicates the behavior similar to its binary analog.

\section{Thermal Properties}

To investigate the thermodynamic properties of Zn-chalcopyrite, we have used Gibbs program. The obtained set of total energy versus primitive cell volume determined in previous section has been used to derive the macroscopic properties as a function of temperature and pressure from the standard thermodynamic relations. Gibbs program is based on the quasi-harmonic Debye model [45], in which the non-equilibrium Gibbs function $G^{*}(V ; P, T)$ can be written in the form of:

$$
G^{*}(V ; P, T)=E(V)+P V+A_{v i b}\left[\theta_{D} ; T\right]
$$

where $\mathrm{E}(\mathrm{V})$ is the total energy per unit cell, PV corresponds to the constant hydrostatic pressure condition, $\theta_{\mathrm{D}}$ is the Debye temperature, and $\mathrm{A}_{\mathrm{vib}}$ is the vibrational term, which can be written using the Debye model of the phonon density of states as $[46,47]$ :

$$
A_{v i b}\left[\theta_{D} ; T\right]=n k T\left[\frac{9 \theta}{8 T}+3 \ln \left(1-e^{-\theta / T}\right)-D\left(\frac{\theta}{T}\right)\right]
$$

where $\mathrm{n}$ is the number of atoms per formula unit, $\mathrm{D}(\theta / \mathrm{T})$ represents the Debye integral, and for an isotropic solid, $\theta$ is expressed as [46]:

$$
\theta_{D}=\frac{\hbar}{k}\left[6 \pi^{2} V^{1 / 2} n\right]^{1 / 3} f(\sigma) \sqrt{\frac{B_{S}}{M}}
$$


$\mathrm{M}$ being the molecular mass per unit cell and $\mathrm{B}_{\mathrm{S}}$ the adiabatic bulk modulus, approximated by the static compressibility [45]:

$$
B_{S} \cong B(V)=V \frac{d^{2} E(V)}{d V^{2}}
$$

$f(\sigma)$ is given by Refs. [45,48, 49]; where $\sigma$ is the Poisson ratio.

Therefore, the non-equilibrium Gibbs function $\mathrm{G}^{*}(\mathrm{~V} ; \mathrm{P}, \mathrm{T})$ as a function of $(\mathrm{V} ; \mathrm{P}, \mathrm{T})$ can be minimized with respect to volume $\mathrm{V}$,

$$
\left(\frac{\partial G^{*}(V ; P, T}{\partial V}\right)_{P, T}=0 .
$$

By solving Eq. (23), one can obtain the thermal equation of state (EOS) V(P, T). The heat capacity $\mathrm{C}_{\mathrm{V}}$ and the thermal expansion coefficient $\alpha$ are given by [41],

$$
\begin{gathered}
C_{V}=3 n k\left[4 D\left(\frac{\theta}{T}\right)-\frac{3 \theta / T}{e^{\theta / T}-1}\right] \\
S=n k\left[4 D\left(\frac{\theta}{T}\right)-3 \ln \left(1-e^{-\theta / T}\right)\right] \\
\alpha=\frac{\gamma C_{V}}{B_{T} V}
\end{gathered}
$$

where $\gamma$ is the Grüneisen parameter, which is defined as:

$$
\gamma=-\frac{d \ln \theta(V)}{d \ln V}
$$

Through the quasi-harmonic Debye model, one could calculate the thermodynamic quantities of any temperatures and pressures of compounds from the calculated $\mathrm{E}-\mathrm{V}$ data at $\mathrm{T}=0$ and $\mathrm{P}=0$.

We have also provided a prediction of the hardness $(\mathrm{H}$ in $\mathrm{GPa})$ and six independent elastic constants $\left(\mathrm{C}_{\mathrm{ij}}\right.$ in $\left.\mathrm{GPa}\right)$ by using the semi-empirical equations developed by Verma and co-authors[50, 51],

$\mathrm{B}=$ Bulk modulus; $\mathrm{K}=0.59$ for $\mathrm{A}^{\mathrm{II}} \mathrm{B}^{\mathrm{IV}} \mathrm{C}_{2} \mathrm{~V}$

$$
\mathrm{H}=\mathrm{K} \mathrm{B} \mathrm{B}^{\mathrm{K}+1}
$$

$$
C_{i j}=A_{i j} \times\left(\frac{k_{B} T_{m}}{\left(Z_{1} Z_{2} Z_{3}\right) \Omega}\right)^{0.15} \quad(\mathrm{i}=1,3,4,6 \text { and } \mathrm{j}=1,2,3,4,6)
$$

$A_{11}=160, A_{12}=100, A_{13}=95, A_{33}=150, A_{44}=55, A_{66}=50$

where $Z_{1} Z_{2}$ and $Z_{3}$ are the ionic charges on the $A, B$ and $C$ elements respectively and the value of product of ionic charge is 48 for $\mathrm{A}^{\mathrm{II}} \mathrm{B}^{\mathrm{IV}} \mathrm{C}_{2}{ }^{\mathrm{V}}$ [50]. The calculated values are presented in Table 3.

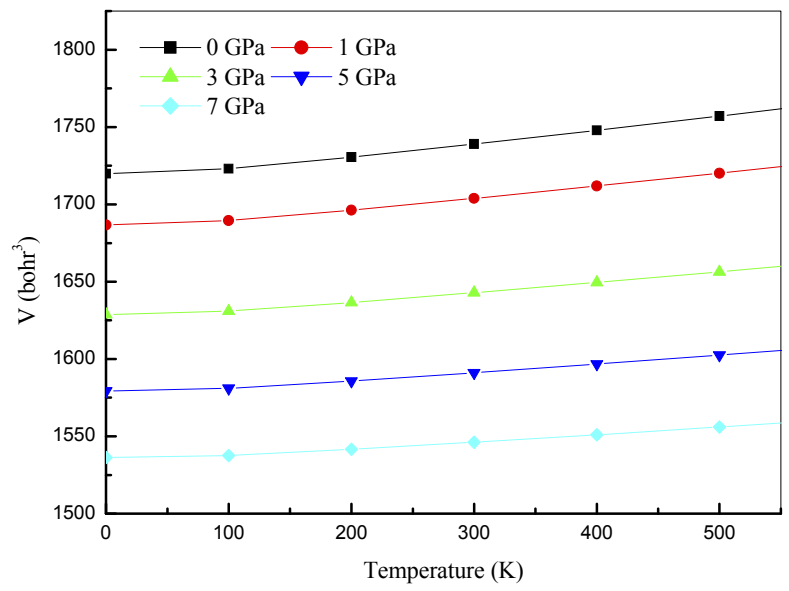

(a)

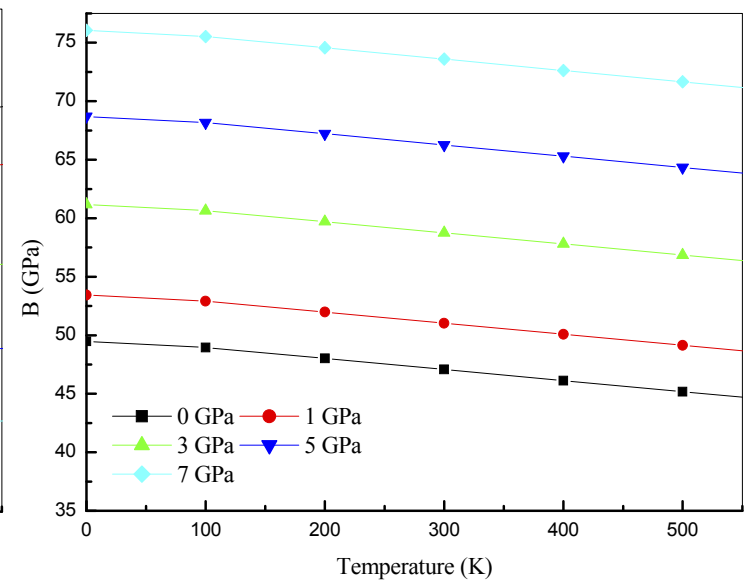

(b)

Fig. 7. The calculated values of (a) Volume (V) and (b) Bulk modulus (B) at different temperature and pressure for $\mathrm{ZnSnSb}_{2}$.

To determine the thermodynamic properties through the quasi-harmonic Debye model, a temperature range $0 \mathrm{~K}-500 \mathrm{~K}$ has been taken. The pressure effects are studied in the 0-7 GPa range. Similar trends have been observed in the considered temperature range, but above $600 \mathrm{~K}$ trends get disturbed which may be due to melting of material. Hence for convenience we have taken $600 \mathrm{~K}$ as the melting temperature $\left(\mathrm{T}_{\mathrm{m}}\right)$ in the proposed study. Fig. 7(a) presents relationships between the equilibrium volume $\mathrm{V}\left(\mathrm{bohr}^{3}\right)$ and pressure at various temperatures. Meanwhile, $\mathrm{V}$ increases 
slightly as the temperature increases, whereas the equilibrium volume $\mathrm{V}$ decreases dramatically as the pressure $\mathrm{P}$ increases at a given temperature. This account suggests that the $\mathrm{ZnSnSb}_{2}$ under loads turns to be more compressible with increasing pressure than decreasing temperature. Fig. 7(b) presents the bulk modulus slightly which decreases with increasing temperature at a given pressure and increases with increasing pressure at a given temperature.

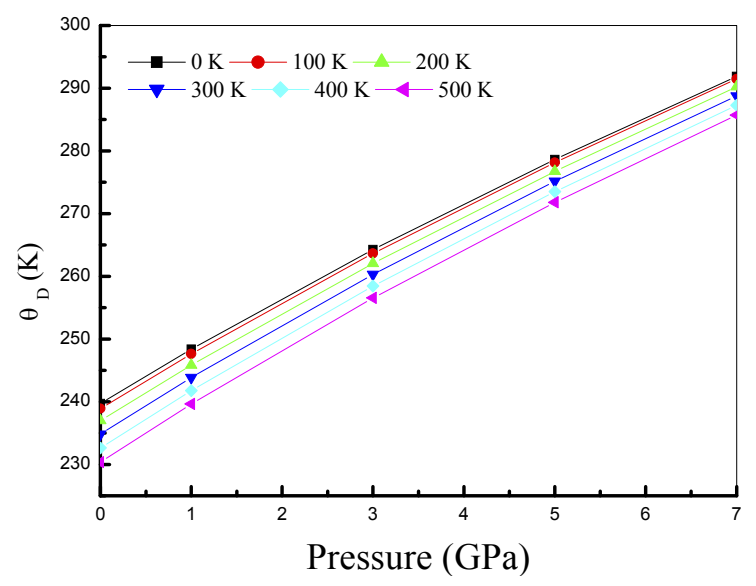

(a)

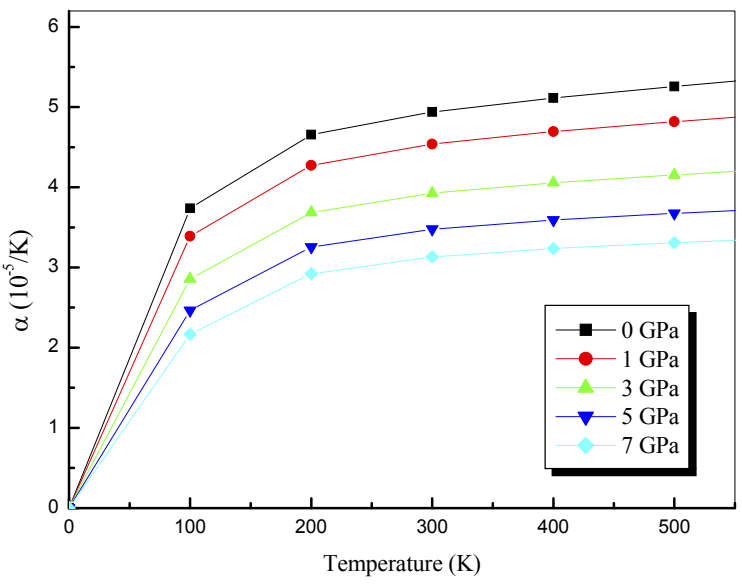

(b)

Fig. 8. (a) Debye temperature and (b) Thermal expansion coefficients at various temperature and pressure for $\mathrm{ZnSnSb}_{2}$.

The variation of the Debye temperature $\theta_{D}(K)$ as a function of pressure and temperature illustrated by proposed results is displayed in Fig. 8(a). With the applied pressure increasing, the Debye temperatures are almost linearly increasing. Fig. 8 (b) shows the volume thermal expansion coefficient $\alpha\left(10^{-5} / \mathrm{K}\right)$ of $\mathrm{ZnSnSb}_{2}$ at various pressures, from which it can be seen that the volume thermal expansion coefficient $\alpha$ increases quickly at a given temperature particularly at zero pressure below the temperature of $300 \mathrm{~K}$. After a sharp increase, the volume thermal expansion coefficient of the $\mathrm{ZnSnSb}_{2}$ is nearly insensitive to the temperature above $300 \mathrm{~K}$ due to the electronic contributions.
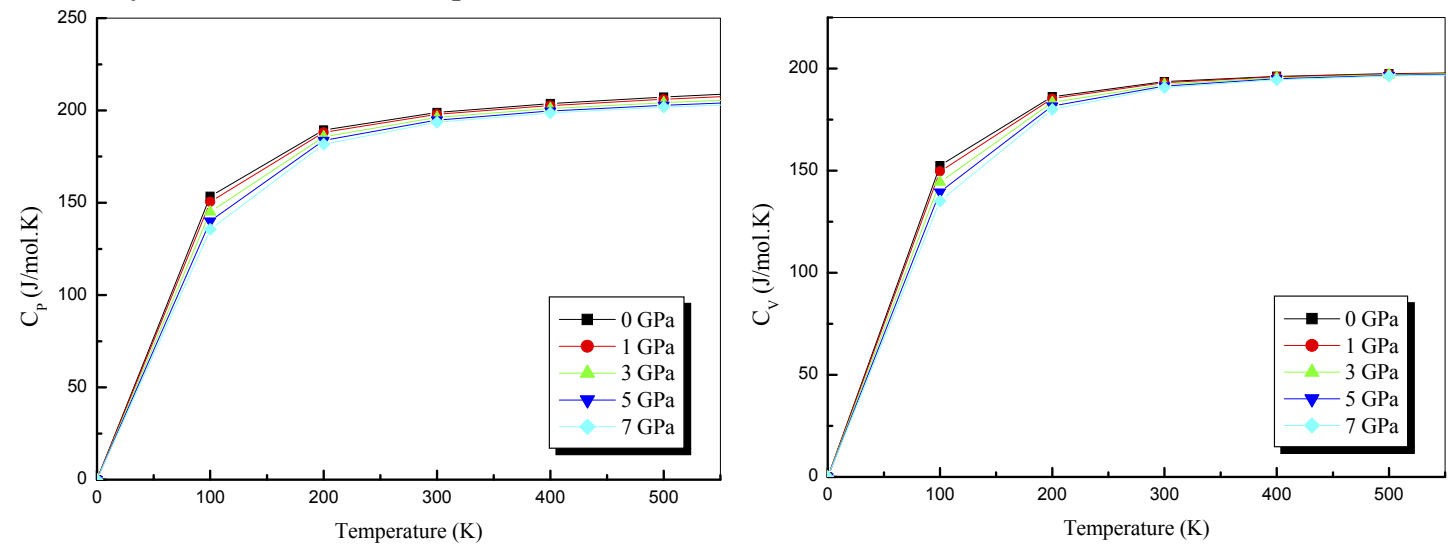

Fig. 9. Heat capacity vs temperature at various pressures for $\mathrm{ZnSnSb}_{2}$.

As very important parameters, the heat capacities of a substance not only provide essential insight into the vibrational properties but are also mandatory for many applications. The proposed calculation of the heat capacities $C_{P}$ and $C_{V}$ of $\mathrm{ZnSnSb}_{2}$ verses temperature at pressure range 0-7 GPa are shown in the following Fig. 9. From this figure, we can see that the constant volume heat capacity $\mathrm{C}_{\mathrm{V}}$ and the constant pressure capacity $\mathrm{C}_{\mathrm{P}}$ are very similar in appearance and both of them are proportional to $\mathrm{T}^{3}$ at low temperatures. At high temperatures, the anharmonic effect on heat capacity is suppressed; which is called Dulong-Petit limit, with the increasing of the temperature, whereas $\mathrm{C}_{\mathrm{P}}$ increases monotonically with the temperature. Fig. 10(a) shows the entropy vs temperature at various pressures for $\mathrm{ZnSnSb}_{2}$. The entropies are variable by power exponent with increasing temperature but the entropies are higher at low pressure than that at high pressure at same temperature. The Grüneisen parameter $\gamma$ is another important quantity for the materials. In Fig. 10(b), we have shown the values of Grüneisen parameter $\gamma$ at different temperatures and pressures. It shows the value $\gamma$ increases as the temperature increases at a given pressure and decreases as the pressure increases at a given temperature.

Table 4.

Selection of thermal properties of $\mathrm{ZnSnSb}_{2}$ at $300 \mathrm{~K}$; isothermal and adiabatic bulk moduli (B and $\mathrm{B}_{\mathrm{S}}$ in $\mathrm{GPa}$ ), Hardness

$(\mathrm{H}$ in $\mathrm{GPa})$, Gruneisen parameter $(\gamma)$, Debye temperature $\left(\theta_{\mathrm{D}}\right.$ in $\left.\mathrm{K}\right)$ and thermal expansion coefficient $\left(\alpha\right.$ in $\left.10^{-5} / \mathrm{K}\right)$,

\begin{tabular}{|c|c|c|c|c|c|}
\hline $\mathrm{B}(\mathrm{GPa})$ & $\mathrm{B}_{\mathrm{S}}(\mathrm{GPa})$ & $\mathrm{H}(\mathrm{GPa})$ & $\gamma$ & $\theta_{\mathrm{D}}(\mathrm{K})$ & $\alpha\left(10^{-5} / \mathrm{K}\right)$ \\
\hline 47.1 & 48.4 & 2.64 & 1.86 & 235 & 4.94 \\
\hline
\end{tabular}


In Fig. 11, we have shown the values of hardness ( $\mathrm{H}$ in $\mathrm{GPa})$ at different temperatures and pressures. It shows the hardness decreases as the temperature increases at a given pressure and increases as the pressure increases at a given temperature. The values of hardness are reported for the first time at different pressure and temperature. Table 4 present the thermal properties such as isothermal bulk modulus, hardness, Grüneisen parameter, Debye temperature and thermal expansion coefficient at $300 \mathrm{~K}$.

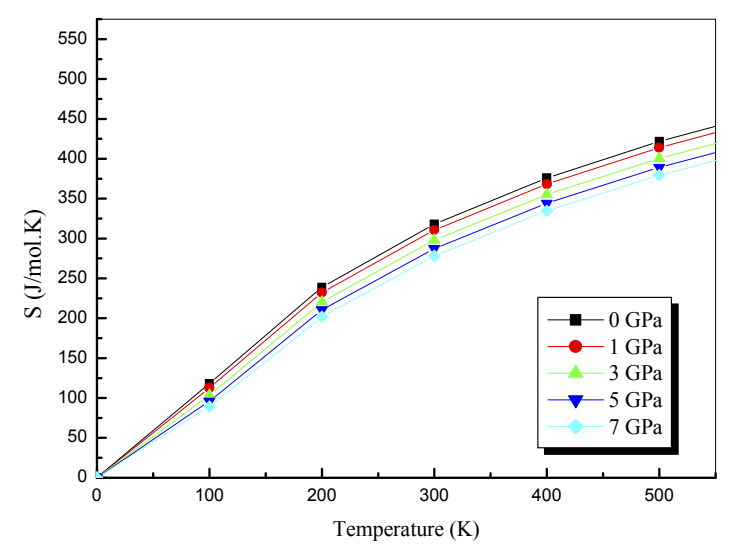

(a)

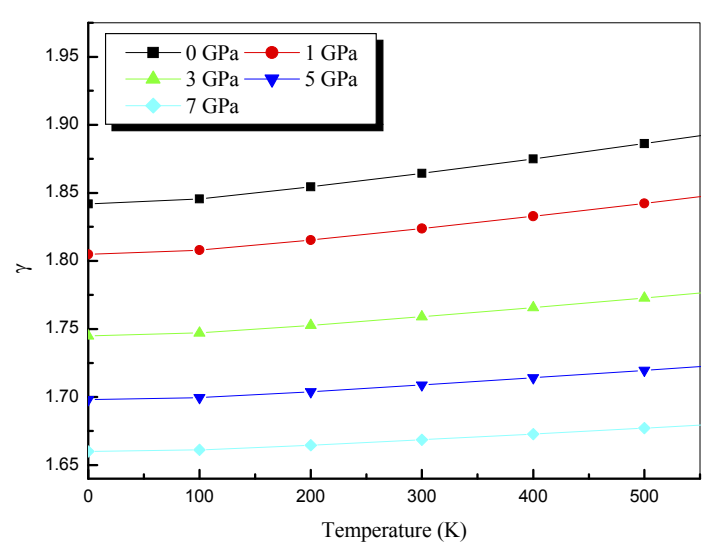

(b)

Fig. 10. Entropy (a) and Gruneisen parameter (b) at various pressures and temperatures for $\mathrm{ZnSnSb}_{2}$

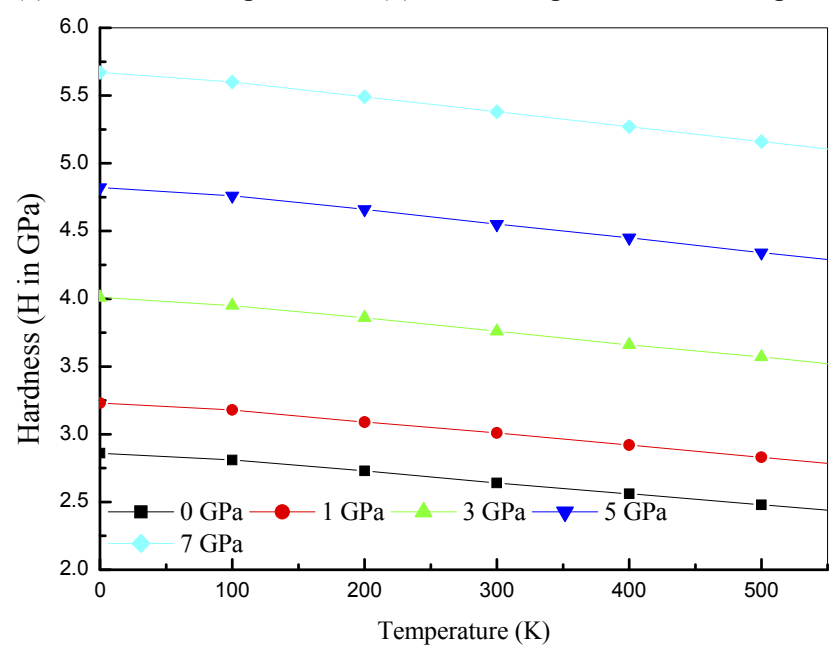

Fig. 11. Hardness vs temperature at various pressures for $\mathrm{ZnSnSb}_{2}$.

\section{SUMMARY AND CONCLUSION}

We have successfully simulated the $\mathrm{ZnSnSb}_{2}$ compound based on the DFT method using the full potential linear augmented plane waves (FP-LAPW), as embodied in the WIEN2k code, and applied the TB-mBJ exchange potential on this system to predict its band gap more precisely. Besides, the calculated partial DOSs indicated that majority of the valence electronic bands correspond to the $\mathrm{p}$ orbitals of antimony atoms which are consistent with those of the other semiconductors of the same group. The proposed result shows that TB-mBJ has significantly improved the electronic structure of the system. A direct band gap of $0.46 \mathrm{eV}$, which is very close to the experimentally measured value of 0.40 $\mathrm{eV}$, was obtained. We have compared electronic, optical and elastic properties with the calculated values of theoretical models $[13,28,29,36,50,51]$. The values are in good agreement with the proposed method and theoretical models. Thermal properties such as Grüneisen parameter, volume expansion coefficient, bulk modulus, specific heat, entropy, Debye temperature and hardness are calculated successfully at various temperatures and pressures, and trends are discussed. To the best of our knowledge, most of the investigated parameters are reported for the first time and hoped to stimulate the succeeding studies.

\section{ORCID IDs}

DShalini Tomar https://orcid.org/0000-0001-7385-3061, (D) Shiv Raj Bhardwaj https://orcid.org/0000-0002-1895-158X,

(D) Saral Kumar Gupta https://orcid.org/0000-0002-0446-8984, (D)Ajay Singh Verma https://orcid.org/0000-0001-8223-7658

\section{REFERENCES}

[1] A.S. Verma, Solid State Communications, 149(29-30), 1236-1239 (2009), https://doi.org/10.1016/j.ssc.2009.04.011.

[2] G. Murtaza, Sibghat-Ullah, R. Khenata, A.H. Reshak and S.S. Hayat, J. Optoelectronics and Advanced Materials, 16(1-2), 110-116 (2014), https://old.joam.inoe.ro/index.php?option=magazine\&op=view\&idu=3402\&catid=82. 
[3] Y. You, B. Zhao, S. Zhu, T. Gao, H. Hou and $\quad$ Z. He, J. Solid State Chem. 185, 264-270 (2012), https://doi.org/10.1016/j.jssc.2011.10.014.

[4] A.S. Verma, Phil. Mag. 89(2), 183-193 (2009), https://doi.org/10.1080/14786430802593814.

[5] S. Kamran, K. Chen and L. Chen, Phys. Rev. B, 77(9), 094109 (2008). https://doi.org/10.1103/PhysRevB.77.094109.

[6] B. Derby, Phys. Rev. B, 76(5), 054126 (2007). https://doi.org/10.1103/PhysRevB.76.054126.

[7] S.Q. Wang and H.Q. Ye, J. Phys. Condens. Matter. 17(28), 4475 (2005). http://dx.doi.org/10.1088/0953-8984/17/28/007.

[8] X. Jiang and W.R.L. Lambrecht, Phys. Rev. B, 69(3), 035201 (2004), https://doi.org/10.1103/PhysRevB.69.035201.

[9] S. Ozakia and S. Adachi, J. App. Phys. 100(11), 113526 (2006). https://doi.org/10.1063/1.2400804.

[10] A. Kosuga, T. Plirdpring, R. Higashine, M.Matsuzawa, K. Kurosaki and S. Yamanaka, App. Phy. Letts. 100(4), 042108 (2012), https://doi.org/10.1063/1.3678044.

[11] J. Łazewski, H. Neumann, P.T. Jochym and K. Parlinski, J. App. Phys. 93(7), 3789-3795 (2003), https://doi.org/10.1063/1.1556179.

[12] S. Limpijumnong, W.R.L. Lambrecht, Phys. Rev. B, 65(16), 165204 (2002),https://doi.org/10.1103/PhysRevB.65.165204.

[13] A.S. Verma and D. Sharma, Phys. Scr. 76(1), 22-24 (2007), https://doi.org/10.1088/0031-8949/76/1/004.

[14] W. Scott, J. Appl. Phys. 44(11), 5165-5166 (1973), https://doi.org/10.1063/1.1662110.

[15] J.L. Shay and J.H. Wernick, Ternary Chalcopyrite Semi-conductors: Growth Electronic Properties and Applications, (Pergamon Press, Oxford, 1975), pp. 11,12,73.

[16] A. Tengå, F.J. Garcia-Garcia, A.S. Mikhaylushkin, B. Espinosa-Arronte, M. Andersson and U.Haussermann, Chem. Mater. 17(24), 6080-6085 (2005), https://doi.org/10.1021/cm0516053.

[17] S. Mishra and B. Ganguli, J. Solid State Chemistry, 200, 279-286 (2013), https://doi.org/10.1016/j.jssc.2013.01.007.

[18] G.K.H. Madsen, P. Blaha, K. Schwarz, E. Sjöstedt and L. Nordström, Phys. Rev. B 64(19), 195134 (2001), https://doi.org/10.1103/PhysRevB.64.195134.

[19] K. Schwarz, P. Blaha and G.K.H Madsen, Comput. Phys. Commun. 147(1-2), 71-76 (2002), https://doi.org/10.1016/S00104655(02)00206-0.

[20] P. Blaha, K. Schwarz, G.K.H. Madsen, D. Kvasnicka, and J. Luitz, WIEN2k: An Augmented Plane Wave+Local Orbitals Program for Calculating Crystal Properties(Karlheinz Schwarz/Techn. Universität, Wien, Austria, 2001).

[21] Z. Wu and R. E. Cohen, Phys. Rev. B 73(23), 235116 (2006), https://doi.org/10.1103/PhysRevB.73.235116.

[22] F. Tran, R. Laskowski, P. Blaha, and K. Schwarz, Phys. Rev. B, 75(11), 115131 (2007), https://doi.org/10.1103/PhysRevB.75.115131.

[23] W. Kohn and L.J. Sham, Phys. Rev. 140, A1133 (1965),https://doi.org/10.1103/PhysRev.140.A1133.

[24] J.P. Perdew, K. Burke, and M. Ernzerhof, Phys. Rev. Lett. 77(4), 3865 (1996), https://doi.org/10.1103/PhysRevLett.77.3865.

[25] F. Tran and P. Blaha, Phys. Rev. Lett. 102(22), 226401 (2009), https://doi.org/10.1103/PhysRevLett.102.226401.

[26] P.E. Blochl, O. Jepsen, O.K. Andersen, Phys. Rev. B 49(23), 16223 (1994), https://doi.org/10.1103/PhysRevB.49.16223.

[27] F.D. Murnaghan, Proc. Natl. Acad. Sci. USA, 30, 244 (1947), https://dx.doi.org/10.1073\%2Fpnas.30.9.244.

[28] A.S. Verma, Mat. Chem. Phys. 139(1), 256-261 (2013), https://doi.org/10.1016/j.matchemphys.2013.01.032.

[29] A.S. Verma and S.R. Bhardwaj, J. Phys: Condensed Matter, 19(2), 026213 (2007), https://oi.org/10.1088/09538984/19/2/026213.

[30] N.N. Kiselyova, A.V. Stolyarenko, T. Gu, W. Lu and A.A. Baikov, (2007), http://lab11.imet-db.ru/publ/pdf/44CD-Kiselyova.pdf

[31] J. Bhosale, A. K. Ramdas, A. Burger, A. Munoz, A. H. Romero, M. Cardona, R. Lauck and R. K. Kremer, Phys. Rev. B, 86(19), 195208 (2012), https://doi.org/10.1103/PhysRevB.86.195208.

[32] J. Sun, H. T. Wang, N.B. Ming, J. He and Y. Tian, Appl. Phys. Letts. 84(22), 4544-4546 (2004), https://doi.org/10.1063/1.1758781.

[33] S. Saha and T.P. Sinha and A. Mookerjee, Phys. Rev. B 62(13), 8828 (2000), https://doi.org/10.1103/PhysRevB.62.8828.

[34] P.Y.Yu and M. Cardona, Fundamentals of Semiconductors, (Springer-Verlag, Berlin, 1996).

[35] M.Q. Cai, Z. Yin and M.S. Zhang, Appl. Phys. Letts, 83(14), 2805-2807 (2003), https://doi.org/10.1063/1.1616631.

[36] A.S. Verma, Phys. Status Solidi B, 246(1), 192-199 (2008), https://doi.org/10.1002/pssb.200844242.

[37] J.F. Nye, Physical Properties of Crystals, Their Representation by Tensors andMatrices, (Oxford Univ.Press, Oxford, USA, 1985).

[38] W. Voigt, Lehrbuch der Kristallphysik, (Teubner, Leipzig, 1928).

[39] I.R. Shein, A.L. Ivanovskii, Scripta Materiali, 59(10), 1099-1102 (2008), https://doi.org/10.1016/j.scriptamat.2008.07.028.

[40] A. Reuss, Z. Angew, ZAMM, 9, 49-58 (1929), https://doi.org/10.1002/zamm.19290090104.

[41] R. Hill, Proc. Phys. Soc. Lond. A, 65, 349 (1952), https://doi.org/10.1088/0370-1298/65/5/307.

[42] S.F. Pugh, Philos. Mag. 45, 823 (1953), https://doi.org/10.1080/14786440808520496.

[43] K. Chen and L. Zhao, J. Appl. Phys. 93(5), 2414-2417 (2003), https://doi.org/10.1063/1.1540742.

[44] K. Chen, L. Zhao, J.S. Tse andJ.R. Rodgers, Phys. Lett. A, 331(6), 400-403 (2004), https://doi.org/10.1016/j.physleta.2004.09.034.

[45] M.A. Blanco, E. Francisco and V. Luaña, Comput. Phys. Commun. 158(1), 57-72 (2004), https://doi.org/10.1016/j.comphy.2003.12.001.

[46] M.A. Blanco, A. Martín Pendás, E. Francisco, J.M. Recio and R. Franco, J. Mol. Struct. Theochem. 368, 245-255 (1996), https://doi.org/10.1016/S0166-1280(96)90571-0.

[47] M. Flórez, J.M. Recio, E. Francisco, M.A. Blanco and A. Martín Pendás, Phys. Rev. B, 66(14), 144112 (2002), https://doi.org/10.1103/PhysRevB.66.144112.

[48] E. Francisco, M.A. Blanco and G. Sanjurjo, Phys. Rev. B,63(9), 094107 (2001), https://doi.org/10.1103/PhysRevB.63.094107.

[49] J.P. Poirier, Introduction to the Physics of Earth's Interior, (Cambridge University Press, Oxford, 2000), pp. 39.

[50] A.S. Verma and S.R. Bhardwaj, J. Phys: Condensed Matter. 19(2), 026213 (2007), https://doi.org/10.1088/09538984/19/2/026213.

[51] A.S. Verma, S. Sharma, R. Bhandari, B.K. Sarkar and V.K. Jindal, Mat. Chem. and Phys. 132(2-3), 416-420 (2012), https://doi.org/10.1016/j.matchemphys.2011.11.047. 


\section{ТЕОРЕТИЧНЕ ДОСЛІДЖЕННЯ ФУНДАМЕНТАЛЬНИХ ФІЗИЧНИХ ТА ОПТОЕЛЕКТРОННИХ ВЛАСТИВОСТЕЙ НАПІВПРОВІДНИКОВОГО ХАЛКОПІРИТУ $\mathrm{ZnSnSb2}$}

\section{Ш. Томар ${ }^{\text {a }}$ Ш.Р. Бхардвай ${ }^{\mathrm{b}}$, С.К. Гупта ${ }^{\mathrm{a}}$, А.С. Верма ${ }^{\mathrm{a}}$}

а Фізичний факультет, Банастхалі Від'япіт, Раджастан, (Індія) 304022

${ }^{b}$ Фізичний факультет, ВSА Коледж Матура, (Індія) 281004

В статті досліджено невід'ємні фундаментальні фізичні властивості, такі як структурні, електронні, оптичні, пружні, теплові тощо для $\mathrm{ZnSnSb}$, використовуючи точний повний потенціал лінеаризованої розширеної плоскої хвилі (FP-LAPW). Ці матеріали мають більш високі енергетичні щілини та нижчі температури плавлення порівняно з їх бінарними аналогами, через що вони вважаються важливими в дослідженнях росту кристалів та в застосуванні для пристроїв. Для структурних властивостей мінімізація проводиться в два етапи, перший параметр и мінімізується шляхом обчислення внутрішніх сил, що діють на атоми всередині одиничної чарунки, поки сили не стануть незначними, для цього використовується завдання МINI, що входить до коду WIEN2K. По-друге, загальна енергія кристала обчислюється для сітки об'єму одиничної чарунки (V) та співвідношення с/а. Для кожного об'єму використовуються п'ять значень с/а, i застосовується поліноміальна підгонка до обчислених енергій, щоб отримання найкращого співвідношення с/а. Ми представили електронні та оптичні властивості 3 нещодавно розробленим функціоналом щільності Tran i Blaha. Крім того, оптичні характеристики, такі як діелектричні функції, показники заломлення, коефіцієнт згасання, оптична відбивна здатність, коефіцієнти поглинання, оптична провідність, розрахували для енергій фотона до $40 \mathrm{eB}$. Для цих властивостей ми використовували WC i TB-mBJ обмінний кореляційний потенціал і отримали величину забороненої зони у діапазоні 0,46 еВ для цього матеріалу, і отримана заборонена зони діапазону добре відповідає експериментальним даним. Потенціал ТВ-mBJ дає хорошу згоду з експериментальними значеннями, подібними до тих, що отримуються більш досконалими методами, але за значно менших обчислювальних витрат. Основні піки реальної частини електронної діелектричної функції $\varepsilon 1(\omega)$, яка в основному генерується електронним переходом від вершини валентної зони до нижньої зони провідності, наступає при $1,59 \mathrm{eB}$, а спектри $\varepsilon 1(\omega)$ далі зменшуються до 4,99 еВ. Уявна частина електронної діелектричної постійної $\varepsilon_{2}(\omega) \epsilon$ основним фактором оптичних властивостей матеріалу. Пропоноване дослідження показує, що критична точка $\varepsilon_{2}(\omega)$ виникає при $0,42 \mathrm{eB}$, що тісно пов'язане 3 отриманим значенням щілини в діапазоні $0,46 \mathrm{eB}$. Максимальна відбивна здатність виникає в області 3,74-11,33 еВ. Цей матеріал має не зникаючу провідність у зоні видимого світла (1,65 еВ - 3,1 eB), основний пік настає при 3,80 еВ, який потрапляє у УФ область. Визначено також пружні константи при рівновазі в структурі ВСТ. Тензор пружної жорсткості сполук халькопіриту має шість незалежних компонентів через властивості симетрії просторової групи, а саме: $\mathrm{C}_{11}, \mathrm{C}_{12}, \mathrm{C}_{13}, \mathrm{C}_{33}, \mathrm{C}_{44}$ та $\mathrm{C}_{66}$ у нотації Юнга. Теплові властивості, такі як теплове розширення, теплоємність, температура Дебая, ентропія, параметр Грюнайзена та об'ємний модуль, були обчислені за допомогою квазігармонічної моделі Дебая при різних температурах і тиску. Для визначення термодинамічних властивостей за допомогою квазігармонічної моделі Дебая було взято температурний діапазон $0 \mathrm{~K}-500 \mathrm{~K}$. Ефекти тиску досліджено в діапазоні 0 - 7 ГПа. Подібні тенденції спостерігаються і в розглянутому діапазоні температур, але вище $600 \mathrm{~K}$ тренди порушуються, що може бути пов'язано 3 плавленням матеріалу. Виходячи 3 напівемпіричного відношення, ми визначили твердість матеріалів, що пов'язано з різною силою ковалентного зв'язку. Про більшість досліджуваних параметрів повідомляється вперше.

КЛЮЧОВІ СЛОВА: обчислення Ab-initio; електронні властивості; оптичні властивості; пружні константи; теплові властивості

\section{ТЕОРЕТИЧЕСКИЕ ИССЛЕДОВАНИЯ ФУНДАМЕНТАЛЬНЫХ ФИЗИЧЕСКИХ И ОПТОЭЛЕКТРОННЫХ СВОЙСТВ ПОЛУПРОВОДНИКОВОГО ХАЛКОПИРИТА ZnSnSb2 Ш. Томар ${ }^{a}$ Ш.Р. Бхардвай ${ }^{b}$, С.К. Гупта ${ }^{a}$, А.С. Верма ${ }^{a}$ \\ ${ }^{a}$ Физический факультет, Банастхали Видьяпит, Раджастан, Индия, 304022 \\ ${ }^{b}$ Физический факультет, ВSА Колледж Матур, Индия, 281004}

В статье исследованы неотъемлемые фундаментальные физические свойства, такие как структурные, электронные, оптические, упругие, тепловые и т.д. для $\mathrm{ZnSnSb}_{2}$, используя точный полный потенциал линеаризованной расширенной плоской волны (FP-LAPW). Эти материалы имеют более высокие энергетические щели и низкие температуры плавления по сравнению с их бинарными аналогами, поэтому они считаются важными в исследованиях роста кристаллов и в применении для устройств. Для структурных свойств минимизация проводилась в два этапа, первый параметр «и» минимизируется путем вычисления внутренних сил, действующих на атомы внутри единичной ячейки, пока силы не станут незначительными, для этого используется задача MINI, которая входит в код WIEN2K. Во-вторых, общая энергия кристалла исчисляется для сетки объема единичной ячейки $(\mathrm{V})$ и соотношения «с/а». Для каждого объема используются пять значений «с/а», и применяется полиномиальная подгонка вычисленных энергий, для получения наилучшего соотношения «с/а». Мы представили электронные и оптические свойства недавно разработанным функционалом плотности Tran и Blaha. Кроме того, оптические характеристики, такие как диэлектрические функции, показатели преломления, коэффициент затухания, оптическая отражательная способность, коэффициенты поглощения, оптическая проводимость, рассчитаны для энергий фотонов до 40 эВ. Для этих свойств мы использовали WC и ТВ-mBJ обменный корреляционный потенциал и получили величину запрещенной зоны в диапазоне 0,46 эВ для этого материала, и полученная ширина запрещенной зоны хорошо соответствует экспериментальным данным. Потенциал ТВ-mBJ дает хорошее согласие с экспериментальными значениями, подобные тем, что получаются более совершенными методами, но при значительно меньших вычислительных затратах. Основные пики реальной части электронной диэлектрической функции $\varepsilon_{1}(\omega)$, которая в основном генерируется электронным переходом от вершины валентной зоны до нижней зоны проводимости, наступает при 1,59 эВ, а спектры $\varepsilon_{1}(\omega)$ дальше уменьшаются до 4,99 эВ. Мнимая часть электронной диэлектрической постоянной $\varepsilon_{2}(\omega)$ является основным фактором оптических свойств материала. Предлагаемое исследование показывает, что критическая точка $\varepsilon_{2}(\omega)$ возникает при 0,42 эВ, что тесно связано с полученным значением щели в диапазоне 0,46 эВ. Максимальная отражательная способность возникает в области 3,74 - 11,33 эВ. Этот материал имеет не исчезающую проводимость в зоне видимого света (1,65 эВ - 3,1 эВ), основной пик наступает при 3,80 эВ, который попадает в УФ область. Определены упругие константы при равновесии в структуре ВСТ. Тензор упругой жесткости соединений халькопирита имеет шесть независимых компонентов через свойства симметрии 
пространственной группы, а именно: $\mathrm{C}_{11}, \mathrm{C}_{12}, \mathrm{C}_{13}, \mathrm{C}_{33}, \mathrm{C}_{44}$ и $\mathrm{C}_{66}$ в нотации Юнга. Тепловые свойства, такие как тепловое расширение, теплоемкость, температура Дебая, энтропия, параметр Грюнайзена и объемный модуль, были вычислены с помощью квазигармонических модели Дебая при различных температурах и давлениях. Для определения термодинамических свойств с помощью квазигармонических модели Дебая было взято температурный диапазон $0 \mathrm{~K}-500 \mathrm{~K}$. Эффекты давления исследованы в диапазоне 0-7 ГПа. Подобные тенденции наблюдаются и в рассматриваемом диапазоне температур, но выше 600 К тренды нарушаются, что может быть связано с плавлением материала. Исходя из полуэмпирического отношения, мы определили твердость материала, что связано с разной силой ковалентной связи. О большинстве исследуемых параметров сообщается впервые.

КЛЮЧЕВЫЕ СЛОВА: расчеты Ab-initio; электронные свойства; оптические свойства; упругие постоянные; тепловые свойства 